\title{
An Estimation Method of Load Drop Amount Using Feature Analysis of Fault Data with a Nonlinear Dynamic Load Model
}

\author{
Hiroyuki Hashimoto Member (Mitsubsihi Electric Corp., Hashimoto.Hiroyuki@aj.MitsubishiElectric.co.jp) \\ Yasuyuki Kowada Member (Mitsubsihi Electric Corp., Kowada.Yasuyuki@df.MitsubishiElectric.co.jp) \\ Yukihiro Onoue Member (Chubu Electric Power Co., Inc., Onoue.Yukihiro@chuden.co.jp) \\ Nobutoshi SaitoＭember (Chubu Electric Power Co., Inc., Saitou.Nobutoshi@ chuden.co.jp) \\ Hisanori Ito Member (Chubu Electric Power Co., Inc., Itou.Hisanori@chuden.co.jp)
}

Keywords: load drop, load model, load dynamic characteristic, system protection scheme

\section{Feature Analysis of Fault Data with Dynamic Load Model}

In power system, load drop can be observed following a severe fault as shown in Fig. 1. It is viewed as one of uncertain factors for the computation of control variables on a frequency stabilizing system for islanded system. For the improvement of control precision, the accurate and fast estimation of load drop amount has essential significance. But such an estimation based on short-term actual power and bus voltage measurements just after clearing the fault is difficult since it contains a transient response due to load dynamic characteristic. We propose a new estimation method for load drop amount using a nonlinear dynamic load model. It utilizes useful pieces of analysis information of load dynamic characteristics, which is derived from actual measurement data on a certain measure point, for effective online estimation. Using actual fault data at several substations in Chubu Electric Power Co., we analyzed the feature of dynamic characteristic on the following dynamic load model:

$$
T_{d} \cdot \dot{P}+P=P_{S}+K_{d} \cdot V \cdot \dot{V}
$$

$P$ : active power, $V$ : bus voltage, $P_{S}$ : static load component, $K_{d}, T_{d}$ : dynamic load characteristic parameter

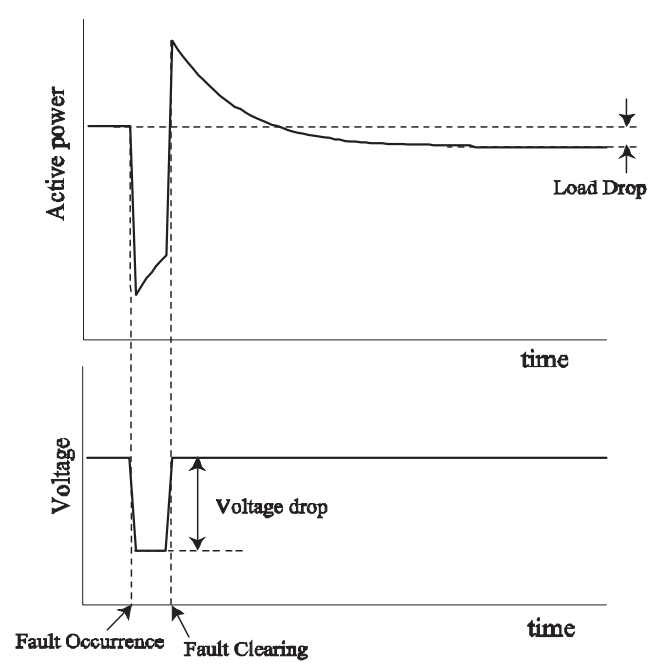

Fig. 1. Active power and voltage measurements in partial load drop
The result shows the interesitng features that $K_{d}-T_{d}$ has linear correlation and $K_{d}$ is well aproximated by quadratic form by voltage drop $\Delta V$ during a fault for a certain measure point.

\section{Proposed Method and Numerical Tests}

Our new method puts the features of dynamic parameters to practical use for fast and accurate online estimation support. It needs an offline preliminary process of making the above mentioned analysis of actual fault measurement data, to get the characteristic information of load dynamic parameters. When a fault actually occures, the method can reproduce the transient response of active power by measured voltage drop just after clearing the fault and subtract it from the actual measurement data of active power to facilitate post fault load amount estimation on the static load component:

$$
P_{S}=P_{0}^{\prime} \cdot\left(K_{p}^{\prime}+K_{z}^{\prime} V^{2}\right)
$$

$P_{0}^{\prime}$ : load level (after clearing a fault), $K_{p}^{\prime}, K_{z}^{\prime}$ : static load characteristic parameter to voltage (after clearing a fault)

Finally the load drop amount is calculated by the difference between the load level before and after the fault.

We present several numerical test results with real fault cases to demonstrate the effectiveness of our method. Fig. 2 shows the result of filtering a transient response from an actual measurement by the method. The estimation error in all cases are within plus or minus $2 \%$ based on the initial load level. These results clearly show good performance and the possibility of improvement in applying for the frequency stabilizing system.

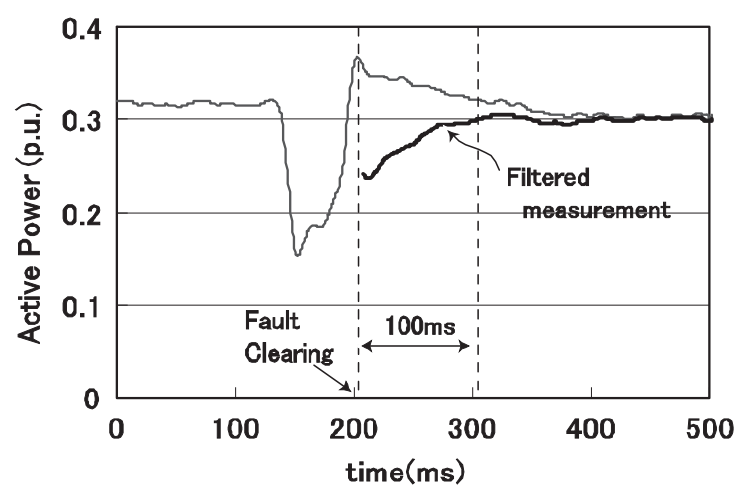

Fig. 2. Filtered active power result by the proposed method 


\title{
動特性負荷モデルによる実故障データの特性分析を利用した 負荷脱落量推定手法
}

\author{
正 員 橋本 博幸* 正 員 小和田靖之** \\ 正 員尾上 幸浩 ${ }^{* * *}$ 正員 斎藤 宣俊 $* * *$ \\ 正 員 伊藤 久徳***
}

\section{An Estimation Method of Load Drop Amount Using Feature Analysis of Fault Data with a Nonlinear Dynamic Load Model}

\author{
Hiroyuki Hashimoto*, Member, Yasuyuki Kowada**, Member, \\ Yukihiro Onoue***, Member, Nobutoshi Saito ${ }^{* * *}$, Member, Hisanori Ito ${ }^{* * *}$, Member
}

\begin{abstract}
In power system, load drop can be observed following a severe fault. It is viewed as one of uncertain factors for the computation of control variable on a frequency stabilizing system for islanded system. The accurate estimation based on short-term actual power and voltage measurements of load just after clearing the fault is difficult since it contains a transient response due to load dynamic characteristic. We propose a new estimation method for load drop amount using a nonlinear dynamic load model. The method utilizes useful pieces of analysis information of load dynamic characteristics, which is derived from actual measurement data on a certain measure point, for effective online estimation. We also present numerical test results with real data of fault cases for validation and demonstrate the effectiveness of our method.
\end{abstract}

キーワード：負荷脱落，負荷モデル，負荷動特性，系統安定化システム

Keywords: load drop, load model, load dynamic characteristic, system protection scheme

\section{1. まえがき}

巨大で複雑な電力系統には, 大規模停電の回避・安定運 用の維持を目的として, 故障発生時に引き起こされる各異 常現象に対応した系統安定化システムが適所に導入されて いる。そのひとつである周波数安定化システムは, 故障発 生時の周波数異常を電源／負荷制限といった制御手段によ り回避し，適正な周波数を維持する役割を担っている。 系統故障発生時には電圧低下に伴って負荷構成機器の一

$*$ 三菱電機（株）先端総合技術研究所

于 661-8661 尼崎市塚口本町 8-1-1

Advanced Technology R\&D Center, MITSUBISHI ELECTRIC

Corporation

8-1-1, Tsukaguchi-honmachi, Amagasaki 661-8661

** 三菱電機 (株) 系統変電システム製作所

干 651-2271 神戸市西区高塚台 1-5-8

Transmission \& Distribution Systems Center, MITSUBISHI

ELECTRIC Corporation

1-5-8, Takatsukadai, Nishi-ku, Kobe 651-2271

*** 中部電力 (株)

于461-8680 名古屋市東区東新町 1 番地

Chubu Electric Power Co., Inc.

1, Toshin-cho, Higashi-ku, Nagoya 461-8680
部が自律的に系統から離脱する現象（負荷脱落）が観測さ れることがある ${ }^{(1)}$ 。負荷脱落発生時に計測点で観測した負 荷量 (有効電力) と負荷母線電圧の波形を図 1 に模式的に 示す。故障除去後の定常状態に復帰したあとの負荷量は脱 落により故障発生前の初期負荷量に比べて小さくなる。連 系系統の故障により単独系統が発生する場合に周波数安定 化システムによる制御は故障除去後数百 $\mathrm{ms}$ 内に実行され るが，このような負荷脱落量は制御量決定時における不確 定要因となり制御結果に大きな影響を与える。したがって 制御精度の向上には負荷脱落量を正確かつ高速に推定する ことが重要となる。

負荷脱落量推定手法としては, いくつかの手法がこれま でに開発されている (2)(3)。これらの手法には, 負荷脱落に起 因した需給アンバランスの結果として観測される周波数偏 差から負荷脱落特性を捉えて制御量を算定する方法や, 統 計的な調査結果から故障時電圧低下率と負荷脱落量の関係 を単純なモデルで捉える方法などがある。前者の手法では 故障直後の系統周波数に故障中の発電機加速の影響が残る ために $1.0 \mathrm{~s}$ 程度以降の周波数偏差しか利用できない。一 方, 後者の手法では故障時に対象系統全体の脱落量を捉え ることを主眼として, 精度は高くないものの統計的に簡素 
化した二段ステップ状モデルを実績データから構築し迅速 な制御を実現するために使用されている。

本論文では，安定化システムにより故障除去後 $200 \mathrm{~ms}$ 以 内にオンライン負荷脱落量推定結果を反映した制御実施を 目指し，上記従来方式と異なるアプローチとして，制御対 象系統内の各計測点における故障前後の負荷量・電圧波形 からオンラインで負荷脱落量を推定する方式を提案する。 本方式は従来方式と対比すると次の特徵を持つ。

（1）変電所既設の計測装置によるローカル負荷系統の 計測波形データに基づいて各計測点の負荷脱落量を推定す る。曜日，季節といった周期性や地域性を考慮することに より負荷のローカルな特性を捉えやすいため, 制御対象系 統全体を対象とするより推定精度の向上が期待できる。

（2）故障除去後の短時間領域（例えば $200 \mathrm{~ms}$ 以内）の 計測データを使用して負荷脱落量を推定する。これにより 故障除去後からの推定完了時間の短縮を図り高速な制御仕 上りが期待できる。

上記の特徵 ( 2 )については, 負荷動特性に起因した過渡 特性が重畳した計測波形となるため，オンラインで負荷脱 落量を精度良く推定するには負荷動特性を考慮する必要が ある。そこで提案方式は，まず動特性を考慮した負荷モデ ルを準備し，適切に分類した故障実績データより分析獲得 した動特性パラメータの特性（特徽（1））を活用して故障 直後の計測波形データから動特性の影響を低減する。そし て主として負荷の静特性分から構成される低減後のデータ に対して，静特性負荷モデルにより推定した故障除去後の 負荷量と初期值との偏差として負荷脱落量を算出する。な お，実際に系統で生じる故障はほとんどが不平衡故障であ るが，周波数安定化システムへの適用を想定し，提案方式 では故障時計測データの正相分の電気量をもとにすべての

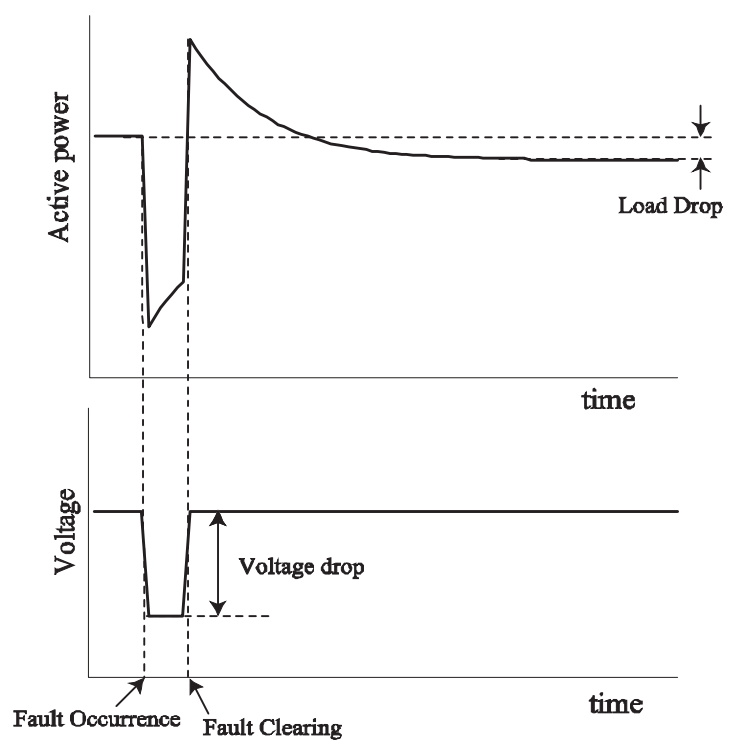

図 1 負荷脱落発生時の電力・電圧計測波形

Fig. 1. Active power and voltage measurements in load drop.
推定演算を実施する。

本論文の構成は以下の通りである。最初に 2 章では，提 案方式で使用する動特性を考慮した負荷モデルについて説 明する。次に 3 章では, 中部電力管内の主要変電所の故障 実績データに基づいた負荷モデルのパラメータ分析より, 動特性パラメータの特性について論ずる。4 章では, 故障 除去後の短時間領域における計測データから負荷脱落量を 推定する新しい方法を提案する。最後に，5章では提案手 法の有効性について実績データを使用して数值検証した結 果を報告する。

\section{2. 動特性を考慮した負荷モデル}

計測点から下位負荷系統を観測したときに，合成負荷特 性の動特性に関わる部分は主としてモーター負荷（誘導機） に起因すると仮定する。誘導機は系統故障除去後に電圧が 回復すると，すべり $s$ を回復するために有効電力を一時的 に大きく消費する。その結果，負荷の有効電力が故障除去 後に過渡的に跳ね上がった後に，急激に減衰する現象が観 測される。

Hill は一般的な誘導機の特性式から動特性を考慮した負 荷モデル式を導出している(4)(5)。負荷モデルの動特性模擬 については, 合成負荷の動特性部分を一機の誘導機として モデル化する。誘導機の運動方程式は以下で与えられる。

$$
\frac{d s}{d t}=\frac{1}{I \omega_{0}^{2}}\left(\frac{P_{m}}{1-s}-P_{d}\right)
$$

ここで, $I$ : 誘導機の慣性定数, $\omega_{0}\left(=2 \pi f_{0}\right)$ : 基準 角速度 $\left(f_{0}\right.$ は基準周波数), $s:$ すべり, $P_{m}$ : 機械 的出力, $P_{d}$ : 電気的入力 (負荷有効電力) である。

図 2 に示す等価回路から有効電力に関する式を導出し, 励 磁インダクタンスが非常に大きいと仮定すると負荷有効電 力は以下のようになる。

$$
P_{d}=\frac{V^{2} R_{m} s}{R_{m}^{2}+X_{m}^{2} s^{2}}
$$

（2）式を微分し運動方程式を代入して整理すると，動特性 負荷について次式が得られる。以降の式では，ある変数 $x$ に対する記述 $\dot{x}$ は時間に関する微分を表すものとする。

$$
\frac{I \omega_{0}^{2}}{V^{2}} \cdot \frac{1}{A(s)} \cdot \dot{P}_{d}+P_{d}=\frac{P_{m}}{1-s}+\frac{I \omega_{0}^{2}}{V^{2}} \cdot \frac{B(s)}{A(s)} \cdot V \cdot \dot{V}
$$

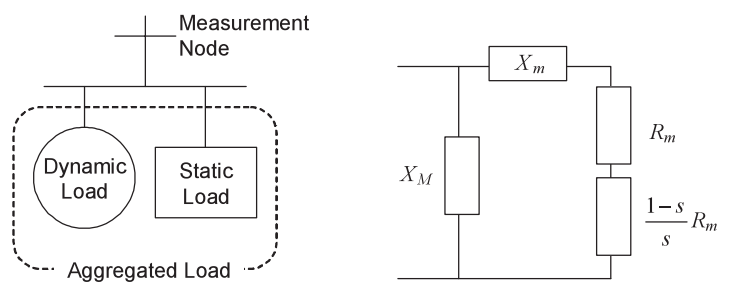

図 2 合成負荷と誘導機の等価回路

Fig. 2. Aggregated load model and induction motor equivalent circuit. 
ここで, $A(s)$ と $B(s)$ はすべり $s$ の関数である。

$$
\left.\begin{array}{l}
A(s)=\frac{R_{m}\left(R_{m}^{2}-s^{2} X_{m}^{2}\right)}{\left(R_{m}^{2}+X_{m}^{2} s^{2}\right)^{2}} \\
B(s)=\frac{2 R_{m} s}{R_{m}^{2}+X_{m}^{2} s^{2}}
\end{array}\right\}
$$

(3) 式の右辺第一項は動特性負荷の定常状態における有効 電力を表している。左辺第一項と右辺第二項は計測点から 見た負荷の動特性を表現している。そこで計測点から見た 静特性負荷を $P_{s t}$ として (3) 式の両辺に加えると以下の (5) 式になる。

$$
\begin{aligned}
& \frac{I \omega_{0}^{2}}{V^{2}} \cdot \frac{1}{A(s)} \cdot \dot{P}_{d}+\left(P_{d}+P_{s t}\right) \\
& \quad=\left(\frac{P_{m}}{1-s}+P_{s t}\right)+\frac{I \omega_{0}^{2}}{V^{2}} \cdot \frac{B(s)}{A(s)} \cdot V \cdot \dot{V}
\end{aligned}
$$

(5) 式に扔いて，新たに次のように变数を定義する。

$$
\left.\begin{array}{c}
P_{d}+P_{s t}=P \\
\frac{P_{m}}{1-s}+P_{s t}=P_{S}
\end{array}\right\}
$$

$P$ は計測点から見て動特性負荷と静特性負荷を統合した合 成負荷を， $P_{S}$ はその合成負荷の静特性分を表す。合成負荷 全体の動特性分はモーター負荷に起因するという前述の仮 定に扔いて，(5) 式を整理すると全体の負荷のモデル式は以 下の (7) 式になる。

$$
\left.\begin{array}{l}
T_{d} \cdot \dot{P}+P=P_{S}+K_{d} \cdot V \cdot \dot{V} \ldots . . \\
T_{d}=\frac{I \omega_{0}^{2}}{V^{2}} \cdot \frac{1}{A(s)} \\
K_{d}=\frac{I \omega_{0}^{2}}{V^{2}} \cdot \frac{B(s)}{A(s)}
\end{array}\right\} \ldots \ldots \ldots \ldots
$$

(7) 式では $K_{d}$ と $T_{d}$ は電圧変動に対する過渡応答の大きさ や応答の長さを決定するパラメー夕になる。本負荷モデル では，動特性負荷の定常有効電力は $P_{S}$ に統合して取り扱 われている。故障除去後に時間が経過すると動特性の影響 が小さくなり, 合成負荷は $P=P_{S}$ となり静特性分のみと なる。また合成負荷の静特性分 $P_{S}$ を次式で与える。

$$
\begin{aligned}
& P_{S}=P_{0} \cdot\left(K_{p}+K_{z} V^{2}\right) \cdots \cdots \cdots \ldots \ldots \ldots \ldots \ldots \ldots \ldots \ldots \ldots \\
& \text { ここで, } K_{p}, K_{z}: \text { 負荷の電圧静特性 }(\text { それぞれ定 } \\
& \text { 電力, 定インピーダンス特性 } \left.\left(K_{p}+K_{z}=1\right)\right), P_{0} \text { : } \\
& \text { 初期負荷量である。 }
\end{aligned}
$$

負荷脱落が発生した場合には故障除去後の負荷の静特性 分のパラメータが変化する。すなわち (9) 式は次式となる。

$$
\begin{aligned}
& P_{S}=P_{0}^{\prime} \cdot\left(K_{p}^{\prime}+K_{z}^{\prime} V^{2}\right) \cdots \ldots \ldots \ldots \ldots \ldots \cdots \cdots \\
& \text { ここで, } P_{0}^{\prime}, K_{p}^{\prime}, K_{z}^{\prime} \text { : 故障除去後の負荷量, 電圧 } \\
& \text { 静特性 }\left(K_{p}^{\prime}+K_{z}^{\prime}=1\right) \text { である。 }
\end{aligned}
$$

故障除去後の電圧が定常状態に復帰し $P_{0}^{\prime}<P_{0}$ であるとき, 負荷脱落量 $\Delta P_{0}$ は故障発生前後の負荷量の差として計算で きる。

$$
\Delta P_{0}=P_{0}-P_{0}^{\prime}
$$

\section{3. 負荷過渡特性に関する分析と検証}

$\langle\mathbf{3} \cdot \mathbf{1}\rangle$ 実績データの分析 中部電力管内の主要変電 所において過去に計測された故障実績データの分析を行っ た。各実績デー夕について, 最小二乗法により動特性負荷 モデル（(7) 式）のパラメータを推定した。故障実績デー夕 の分析に関する諸元は以下の通りである。

•計測期間 ‥ 1998 年 2000 年

・計測点と計測デー夕 $\quad \cdots \quad 77 \mathrm{kV}$ 変電所 (5 箇所) の変 圧器二次側で計測した PVデー夕 (正相分)

- 故障種別 … 系統側 (一次側) で発生する故障ケー 又（自回線故障，多重故障ケースは除外）

・分析方法 … 計測データに対して動特性負荷モデル のパラメータを最小二乗法により推定

- 分析デー夕区間 $\cdots$ 故障除去前 $10 \mathrm{~ms}$ から故障除去 後 $500 \mathrm{~ms}$ 間のデー夕を使用

図 3 は, 計測点 $\mathrm{A}$ と計測点 $\mathrm{B}$ で計測された負荷脱落のな い系統故障ケースの実績データの中で夏季昼間（5９月， 8：00〜19：00）に抢けるデー夕を分析し $K_{d}-T_{d}$ の関倸を それぞれ示したものである。また図中に示す $R^{2}$ は決定係 数であり, 回帰式により説明できた変数の変動割合を示し ている。すなわち， $R^{2}$ は 1 に近いほど回帰式の精度が良い ことを示す。図より以下のことがわかる。

・計測デー夕を季節や時間带, 計測地点により分類すれ ば, 本負荷モデルの動特性パラメータ $K_{d}$ と $T_{d}$ に強い 線形相関がある。

- $K_{d}$ と $T_{d}$ の近似直線の傾きは, 計測デー夕の分類条件 により異なり，負荷のローカルな特性を示している。

- 負荷脱落による影響を見るために脱落ケースの点 $\left(K_{d}\right.$, $T_{d}$ ）を白抜きの点で図に重ねて示したところ, 計測点 $\mathrm{A}$ と B の両者とも脱落のないケースによる近似直線に 近い位置にある。負荷脱落により $K_{d}$ と $T_{d}$ はそれぞれ 影響を受けるが，両者の比は負荷脱落の影響をほとん

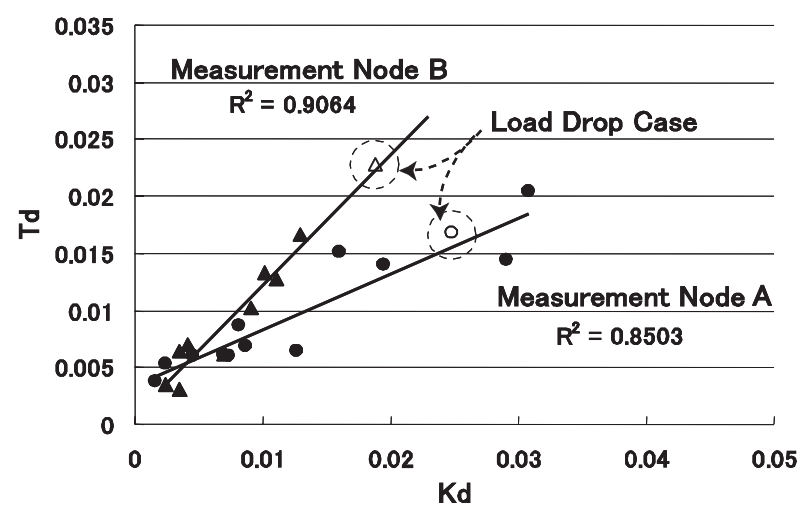

図 3 実績データにおける動特性パラメータ $K_{d}$ と $T_{d}$ の特性（計測点 $\mathrm{A}, \mathrm{B}$ : 夏季 5 9 月, 平日昼間 $8: 00 \sim 19: 00$ )

Fig. 3. Relationship between dynamic load model parameter $K_{d}$ and $T_{d}$. 
ど受けないと考えられる。

〈3.2〉動特性パラメータ分析結果の考察 動特性パ ラメータ $K_{d}$ と $T_{d}((8)$ 式) の比をとり(4) 式を代入して整 理すると以下になる。

$$
\frac{T_{d}}{K_{d}}=\frac{1}{B(s)}=\frac{R_{m}^{2}+X_{m}^{2} s^{2}}{2 R_{m} s}
$$

これは, $T_{d} / K_{d}$ の值は動特性負荷の回路定数 $R_{m}, X_{m}$ とす べり $s$ にりり決定することを示している。〈3・1 節の分析 結果によれば $T_{d} / K_{d}$ 比はほぼ一定になる。これは以下の理 由によると考えられる。

（A）回路定数は計測点から見た負荷の構成に依存する。 ある計測点において負荷特性の周期性を考慮して，たとえ ば季節，曜日，時間带等により計測デー夕を分類して扱え ば，各デー夕に対して負荷構成は大きく変わらず回路定数 はほぼ同じである。

(B) 一般的な誘導機ではすべり $s$ は 0 に近い領域で運 転されている。また，大容量機ではトルク-すべりの関倸を 示す速度特性曲線の傾きは大きく，また慣性定数が大きい ため電圧低下に対するすべりの変化は小さいと考えられる。 つまり, 故障発生後に運転を継続している誘導機のすべり $s$ は大きく変化しない。

$\langle\mathbf{3} \cdot \mathbf{3}\rangle$ 電圧低下率と動特性パラメータ $\quad K_{d}$ は (8) 式 にしたがって以下の式で与えられる。

$$
K_{d}=\frac{I \omega_{0}^{2}}{V^{2}} \cdot \frac{B(s)}{A(s)}=\frac{I \omega_{0}^{2}}{V^{2}} \cdot \frac{2 s\left(1+\left(s \cdot \frac{X_{m}}{R_{m}}\right)^{2}\right)}{1-\left(s \cdot \frac{X_{m}}{R_{m}}\right)^{2}}
$$

$I$ と $\omega_{0}$ は定数であることから〈3・2〉節の考察結果を踏 まえると, $K_{d}$ は主として故障発生時に電圧の二乗の逆数に 関係すると考えられる。ここで, 故障発生時に初期電圧 $V$ $(1.0$ p.u. とする $)$ から $\Delta V(\Delta V \geq 0)$ の電圧低下が発生する ものとする。故障除去後の有効電力の変動については, 故 障発生により低下した電圧が回復する場合の電圧変化分に 依存する。故障除去後の電圧はほぼ初期電圧に戻るため, 電圧変化分は故障発生時の電圧低下分と同じとする。この とき $K_{d}$ は $(1-\Delta V)^{2}$ の逆数に依存するので, これらを展 開して二次までの項をモデル化すると次式となる。ただし， 物理的な観点から定数項は 0 とする。

$$
K_{d}=a_{1} \Delta V+a_{2} \Delta V^{2}
$$

図 4 と図 5 はく $3 \cdot 1\rangle$ 節と同じデー夕を使用して, 変電

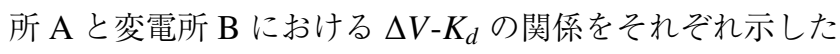
ものである。また図 3 と同様に負荷脱落発生ケースを白抜 きの点で図に重ねて表す。これらの図より以下のことがわ かる。

・ $K_{d}$ は電圧低下率に対して強い依存性を持つ。モデル (14) 式はその特性をよく近似している。

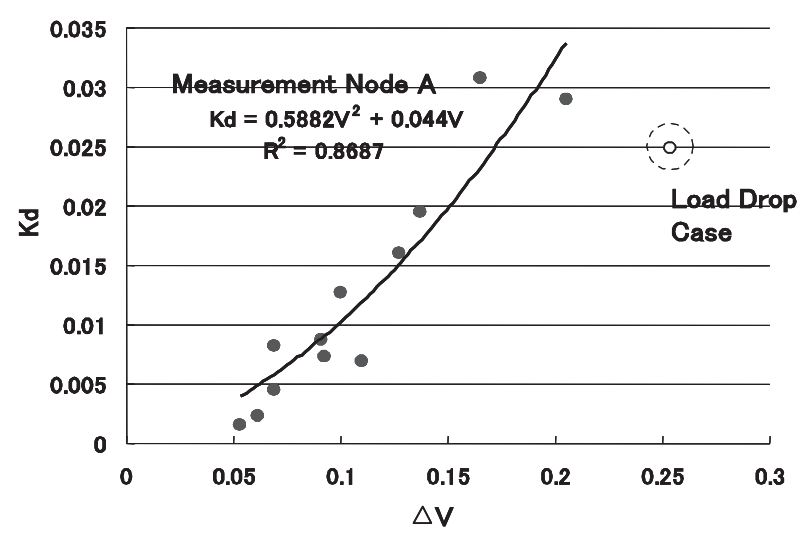

図 4 実績データにおける $K_{d}$ と電圧低下率 (計測点 A)

Fig. 4. Characteristic of dynamic load model parameter $K_{d}$ to voltage drop ratio $\Delta V$ (measurement node A).

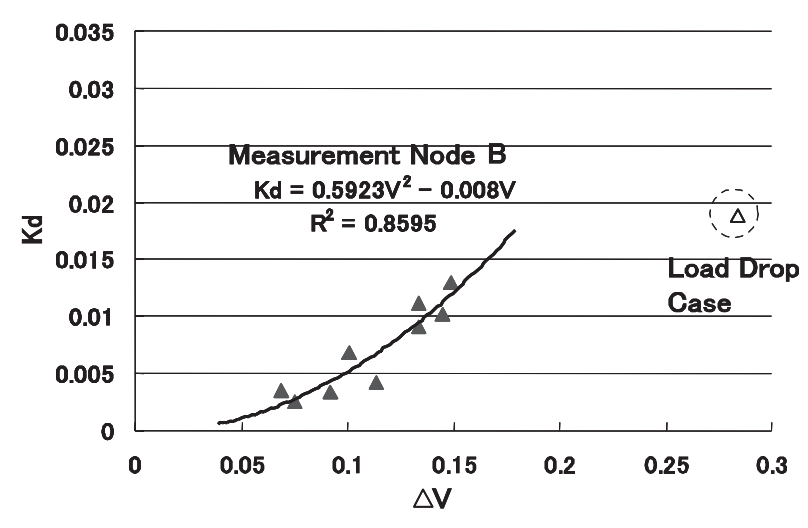

困 5 実績データにおける $K_{d}$ と電圧低下率 (計測点 B)

Fig. 5. Characteristic of dynamic load model parameter $K_{d}$ to voltage drop ratio $\Delta V$ (measurement node B).

・負荷脱落の影響により $K_{d}$ はモデル (14) 式から推定さ れる值と異なり小さい值となる。

\section{4. 負荷脱落量推定手法の提案}

$\langle\mathbf{4} \cdot \mathbf{1}\rangle$ 提案手法 故障除去後の短時間領域の計測デー 夕に基づいて負荷脱落量を推定するために, 動的負荷モデル をべースに過去の実績データから得られる分析情報を活用 した新しい推定手法を提案する。提案手法は変電所既設の 計測装置によるローカル負荷系統の計測波形デー夕を利用 して各計測点の負荷脱落量を推定するものである。ここで 分析情報とはく3・2〉節と〈3.3 節でそれぞれ明らかになっ た負荷モデルの動特性パラメー夕に関する特性である。提 案手法を周波数安定化システムに適用することを考えると, 制御仕上がり時間は約 $200 \mathrm{~ms}$ であるため負荷脱落量推定 演算に要する時間は $100 \mathrm{~ms}$ 程度が望ましい。したがって, 推定演算に使用する計測波形デー夕は故障除去後 $100 \mathrm{~ms}$ 分 とする。また，今回検討に用いた故障実績データでは, 故 障除去後の短時間領域に扔いて周波数変動による負荷変化 が電圧変動による変化に対して小さいため, 本論文では簡 


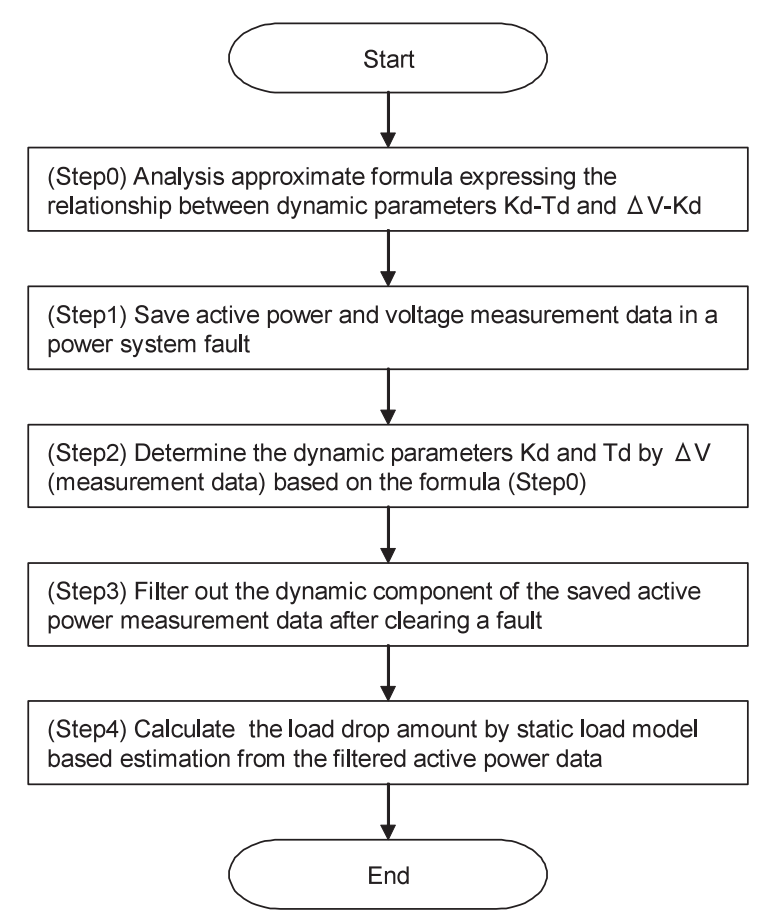

図 6 提案手法のフローチャート

Fig. 6. Flow diagram of proposed method.

単化のため負荷の周波数特性を無視している。

提案手法は図 6 に示すフローチャートにしたがった手順 で構成される。各手順の内容について説明する。（Step 0) は動特性パラメータに関する特性式を分析するために，系 統故障発生前にあらかじめ実行するオフライン処理である。 (Step 0)では過去に計測保存された故障実績データから負 荷脱落のない故障ケースを計測条件（季節，時間带，計測地 点など）により分類して負荷モデル (7) 式に基づいて分析 し, 動特性パラメータ $K_{d}-T_{d}$, また電圧低下率 $\Delta V-K_{d}$ の関 係を統計的に処理し特性式 $\left(K_{d}-T_{d}\right.$ の近似直線, $\Delta V-K_{d}$ の 近似曲線 (14) 式) を作成する。実際に故障が発生した場合 には，(Step 1) 以降の手順によりオンライン処理を実行し 負荷脱落量を算出する。（Step 1)では故障発生時に故障前 数十 $\mathrm{ms}$ から故障除去後 $100 \mathrm{~ms}$ 間の有効電力・電圧の波形 データを計測する。次に (Step 2)では計測データから電圧 低下率 $\Delta V$ を求め, 事前に $($ Step 0) で分析した特性モデル を使用して動特性パラメータを決定する。そして (Step 3) では (Step 2) で求めた動特性パラメータを用いて過渡特性 分の時系列応答を作成する。故障除去後の有効電力計測波 形 (100 ms 分) から作成済み時系列応答を差し引いて負荷 の過渡特性を低減し, 静特性の影響のみを含む波形データ を作成する。最後に (Step 4)では求めた波形デー夕を使用 し静特性モデルに基づいて負荷脱落量を推定する。

〈4·2〉動特性パラメータの推定 提案手法では負荷脱 落がない故障ケースから分析した $\Delta V-K_{d}$ の特性モデル (14) 式を利用して動特性パラメータを推定する。そのため提案 手法は負荷脱落の発生時に $K_{d}$ の推定に誤差を含む。これ は動特性パラメータが負荷脱落の影響を受けていることが
原因である。〈3・3〉節の実績デー夕分析結果において，負 荷脱落発生ケースは特性モデル (14) 式から推定される值よ りも小さい值をとることからも分かる。

一方，〈3・1〉節で述べたように $K_{d}-T_{d}$ の特性モデル式は 負荷脱落の有無による影響を受けないため，本手法では主 として特性モデル (14) 式による $K_{d}$ 推定時に誤差が含まれ ることになる。

ここで $K_{d}$ の推定誤差について定性的な考察を加える。故 障時の電圧低下による負荷脱落には合成負荷の動特性分を 構成する機器の一部脱落が含まれている。電圧低下が増大 するに伴い, 動特性分を構成する機器の負荷脱落量も増大 すると推察される。このとき故障除去直後の過渡特性を引 き起こす要因は小さくなることになる。このことから大幅 な電圧低下が発生する場合には真值からの誤差は増大する が, 有効電力計測波形データに重畳する過渡特性分は縮小 すると予想される。この場合, 提案手法は $K_{d}$ を過大に見積 もり脱落量推定精度の低下の原因になる可能性がある。ま た，大幅な電圧低下時には負荷脱落量の飽和が観測される ことがある。提案手法は動特性パラメー夕を電圧低下率に 基づいて推定し計測波形データにしたがって適応的に脱落 量を推定するため, 脱落量の飽和は推定精度に直接的に影 響するものではなく，この場合にも $K_{d}$ の推定誤差が本質 的に影響する。

$\langle\mathbf{4} \cdot \mathbf{3}\rangle$ 過渡特性の低減処理 電圧低下に起因する故 障除去後の過渡特性部分 $P_{d y n}$ の時系列応答は以下の式に より求める。演算にあたっては，故障時に計測された電圧 $V$ の時系列データと (Step 2) で決定した動特性パラメータ $K_{d}, T_{d}$ を用いる。

$$
T_{d} \cdot \dot{P}_{d y n}+P_{d y n}=K_{d} \cdot V \cdot \dot{V}
$$

上記演算により求められた時系列応答データ $P_{d y n}$ を有効 電力計測波形から除去することにより負荷の過渡特性を低 減する処理を実現する。〈4・2〉節で述べたように負荷脱落 の発生時には動特性パラメー夕に推定誤差があるため, 過 渡特性の低減処理後の有効電力波形に時間とともに減衰す る誤差分が残ることになる。

$$
\hat{P}_{s}=P_{s}+\varepsilon_{P d}
$$

$\varepsilon_{P d}$ : 低減処理後の動特性誤差分

〈4・4〉 負荷脱落量の推定 処理後の波形 $\hat{P}_{s}$ に対して 静特性モデル ((10) 式) のパラメータ推定を行い故障除去後 の負荷量 $P_{0}^{\prime}$ を求める。(11) 式にしたがって, 算出した $P_{0}^{\prime}$ と初期負荷量 $P_{0}$ の差として負荷脱落量 $\Delta P_{0}$ を計算する。

\section{5. 故障実績データによる提案手法の検証}

〈5・1〉 検証条件の設定 中部電力管内で過去に計測 された故障実績データを使用して提案手法の有効性を検証 する。検証条件を以下のように設定する。

（1）〈3・1〉節に示した故障ケースの中から, 変電所 A 
で計測された故障実績データを対象とし（夏季，昼間）の データを抽出

（2）抽出デー夕を負荷脱落が観測された故障ケース（1 ケース）と負荷脱落のない故障ケース（13 ケース）に分類

（3）負荷脱落のない故障ケースを「過去に観測された 実績ケース」として (Step 0)で使用

（4）負荷脱落が観測された故障ケースを「発生故障ケー ス」とし (Step 1)〜 (Step 4)で使用

発生故障ケースの電圧，有効電力の実測波形をそれぞれ 図 7 と図 8 に示す。図 8 から故障除去直後に過渡応動が約

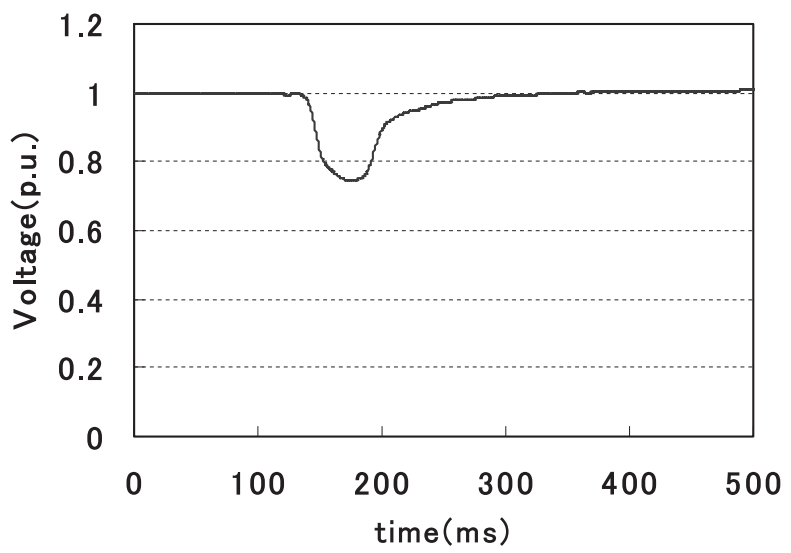

図 7 発生故障ケースにおける電圧計測波形

Fig. 7. Voltage measurement of the fault case with load drop.

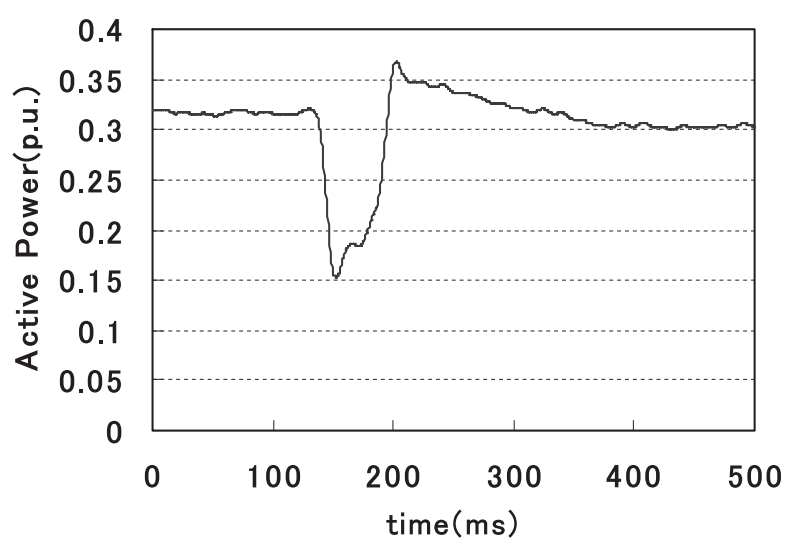

図 8 発生故障ケースにおける有効電力計測波形

Fig. 8. Active power measurement of the fault case with load drop.

表 1 発生故障ケースの負荷モデル・パラメータ

Table 1. Load model parameters of the fault case.

\begin{tabular}{l|c}
\hline$P_{0} \quad$ (p.u.) & 0.317 \\
\hline$P_{0}^{\prime} \quad$ (p.u.) & 0.304 \\
\hline Load drop amount (p.u.) & 0.013 \\
(Load drop ratio) & $(4.1 \%)$ \\
\hline$K_{d}$ & 0.0249 \\
\hline$T_{d}$ & 0.0167 \\
\hline
\end{tabular}

$200 \mathrm{~ms}$ 続いていることが分かる。また，本ケースについて， 故障除去後 $500 \mathrm{~ms}$ 分のデータを用いてあらかじめ分析し た負荷モデルのパラメータを表 1 に示す。

〈5・2〉 検証結果 提案手法の (Step 0)に基づき，動特 性パラメータの特性モデル式を求めると以下のようになる。

$$
\left.\begin{array}{l}
K_{d}=0.5882 \cdot \Delta V^{2}+0.044 \Delta V \\
T_{d}=0.5018 \cdot K_{d}+0.0034
\end{array}\right\}
$$

計測波形から求めた $\Delta V=0.25$ (17) 式に代入して $K_{d}=0.0478, T_{d}=0.0274$ を得る。これらを用いて (15) 式 より故障除去後 $100 \mathrm{~ms}$ 間（計測可能時間）の電圧計測波 形に沿って求めた動特性部分の時系列波形 $P_{d y n}$ を図 9 に 示す。

そして有効電力計測波形（図 8）から $P_{d y n}$ を除去した故 障除去後の波形を図 10 に示す。過渡特性分の低減処理後の 波形 $\hat{P}_{s}$ (100 ms 分) に基づいて (10) 式を用いてパラメータ を推定すると故障後負荷量 $\hat{P}^{\prime}{ }_{0}=0.306$ となり, 負荷脱落量 は $\Delta P_{0}=0.011$ （負荷脱落率 $3.5 \%$ ）である。本結果より故 障除去直後の短時間領域の計測波形から真值 $\left(P_{0}^{\prime}=0.304\right.$, 真值に対する誤差率 $0.6 \%\left(P_{0}\right.$ ベース $\left.)\right)$ に近い良好な結果 が得られたことがわかる（このとき推定された電圧静特性

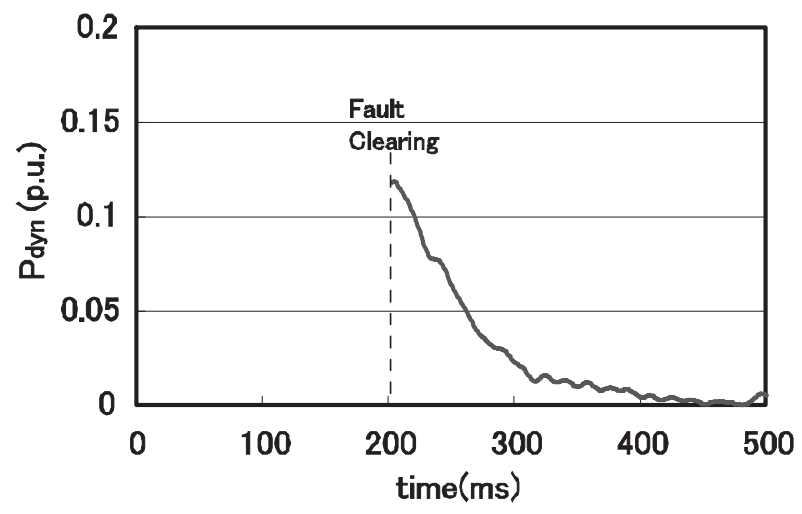

図 9 動特性部分の時系列応答 $P_{d y n}$

Fig. 9. Time-series response of load transient component $P_{d y n}$.

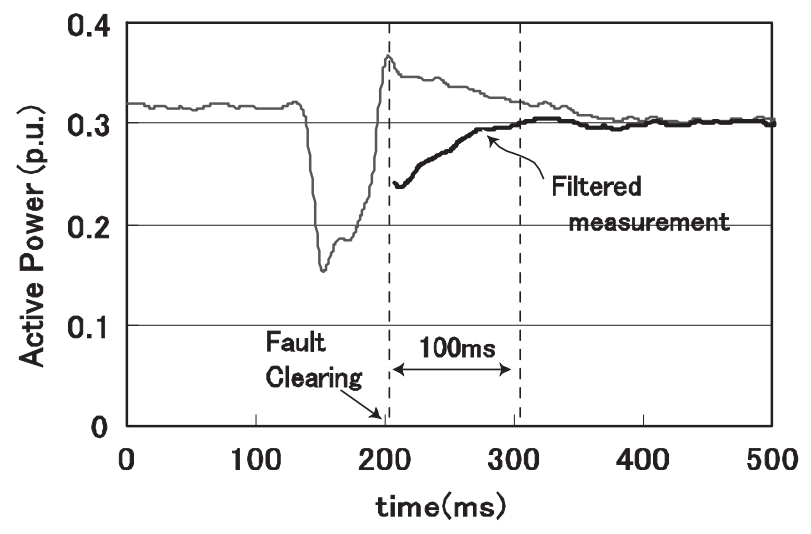

図 10 提案手法適用後の有効電力波形

Fig. 10. Filtered active power result by the proposed method. 
係数は $K_{p}^{\prime}=-0.81, K_{z}^{\prime}=1.81$ であった)。

比較データとして, 図 7 と図 8 に示す観測原波形の故障 除去直後 $100 \mathrm{~ms}$ 分のデータを直接用いて故障除去後負荷量 を推定する。具体的には, 負荷モデル (7) 式の全パラメー 夕を最小二乗法により推定する。このとき故障除去後の負 荷量は $P_{0}^{\prime}=0.338$ となり, 負荷脱落量は $\Delta P_{0}=-0.022$ で ある。故障除去直後の短時間領域の計測波形に基づいて単 純なパラメータ推定を行う場合, 過渡特性分は正確な負荷 脱落量推定を阻害することがわかる。提案手法による上記 結果と比較すると，提案手法により過渡特性分を低減した 有効性が確認できる。

検証結果について以下に考察する。提案方式では観測原 波形から過渡特性分を低減することにより，故障除去後の 定常状態の負荷量を計測可能時間 $(100 \mathrm{~ms})$ に近い時間領 域で捉えることができるように原波形を整形する。これは 図 10 から低減後の有効電力波形が計測期間中にほほ故障 除去後の定常状態に近い負荷量に達していることから確認 できる。 $K_{d}$ に推定誤差が明示的に含まれるが，計測点に固 有の $K_{d}-T_{d}$ 特性に基づいて $K_{d}$ に有意に対応する $T_{d}$ を使用 することにより，提案方式では誤差量に関わらず過渡特性 分を有効に低減するように作用し，原波形に比べて故障除 去後の定常状態の負荷量を早い時間に観測する効果を与え る。故障除去後の負荷量は (10) 式（合成負荷の静特性分） において全体の比例係数として与えられるため，最小二乗 法による推定時に負荷量推定の精度向上に有効に寄与する と考えられる。また， $K_{d}$ の誤差により過渡特性分の低減 処理時に故障除去直後に回復する有効電力波形に誤差分が 重畳する（(16) 式参照)。(10) 式では電圧静特性係数 $\left(K_{p}^{\prime}\right.$, $\left.K_{z}^{\prime}\right)$ は負荷量に比べて推定時の自由度が高いため，上述の ように故障除去後の定常状態の負荷量を計測可能時間に近 い時間領域で観測できるとき，定常状態の負荷量に合わせ るように推定が行われ，回復波形に重畳した誤差分の影響 から電圧静特性係数は真值と異なる結果となる。(本論文の 主眼である負荷脱落量推定という点では, その推定結果は ここでは特に問題ではない)

〈5・3〉他の実績データによる基本性能検証計測地 点や観測時期といった変電所計測データの分類条件の違い による推定精度への影響を検証する。上記 $\langle 5 \cdot 2\rangle$ 節で使用 した検証データと異なる 4 つの計測点（B， C, D, E）で 観測時期の異なる実績データに対して，同様な検証条件を 設定し負荷脱落発生ケースを用いて提案手法の基本性能を 検証した。検証結果のまとめを表 2 に示す。そして計測点 $\mathrm{B}, \mathrm{C}, \mathrm{D}, \mathrm{E}$ に対して有効電力計測波形から $P_{d y n}$ を除去し た故障除去後の波形をそれぞれ図 11 図 14 に示す。検証 した全てのケースにおいて，故障後負荷量の真值に対する 誤差率は $1 \%$ 台であった。したがって，各計測点で季節や 時間帯といった負荷構成に影響を与える周期性を考慮して 実績データを分類し提案手法を適用すれば，良好な結果が 得られることがわかる。

以上の結果から，計測実績データの分類条件を適切に設
表 2 他の計測点における検証結果

Table 2. Estimation results on other measurement nodes.

\begin{tabular}{|c|c|c|c|c|c|}
\hline Node & $\begin{array}{c}\text { number of cases } \\
\text { (case condition) }\end{array}$ & $P_{0}$ & $P_{0}^{\prime}$ & $\hat{P}_{0}^{\prime}$ & $\begin{array}{c}\text { error ratio } \\
\left(P_{0} \text { base }\right)\end{array}$ \\
\hline $\mathrm{B}$ & $\begin{array}{c}10 \text { cases } \\
\text { (summer, daytime) }\end{array}$ & 0.220 & 0.178 & 0.174 & $\cdot 1.8 \%$ \\
\hline $\mathrm{C}$ & $\begin{array}{c}13 \text { cases } \\
\text { (summer, night) }\end{array}$ & 0.453 & 0.429 & 0.422 & $-1.5 \%$ \\
\hline $\mathrm{D}$ & $\begin{array}{c}5 \text { cases } \\
\text { (except summer, } \\
\text { daytime) }\end{array}$ & 0.513 & 0.495 & 0.500 & $1.0 \%$ \\
\hline $\mathrm{E}$ & $\begin{array}{c}14 \text { cases } \\
\text { (summer, daytime) }\end{array}$ & 0.163 & 0.158 & 0.156 & $\cdot 1.2 \%$ \\
\hline
\end{tabular}

$\left(P_{0}^{\prime}:\right.$ true load level after clearing a fault, $\hat{P}_{0}^{\prime}$ : estimated load level)

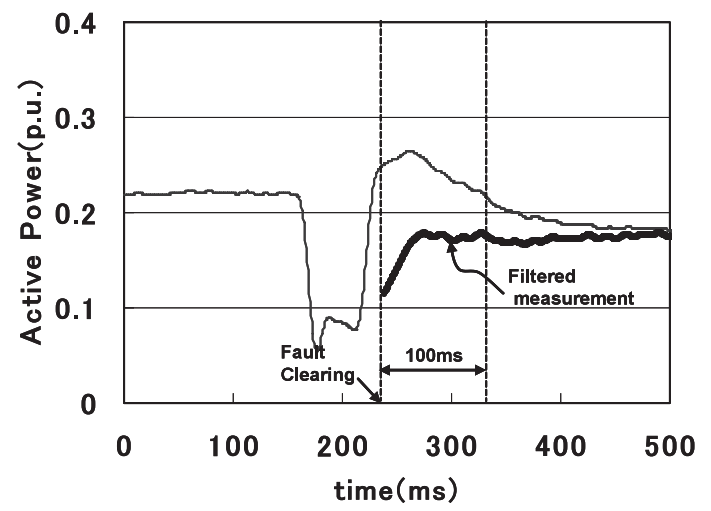

図 11 計測点 B における提案手法適用後の 有効電力波形

Fig. 11. Filtered active power result by the proposed method (measurement node B).

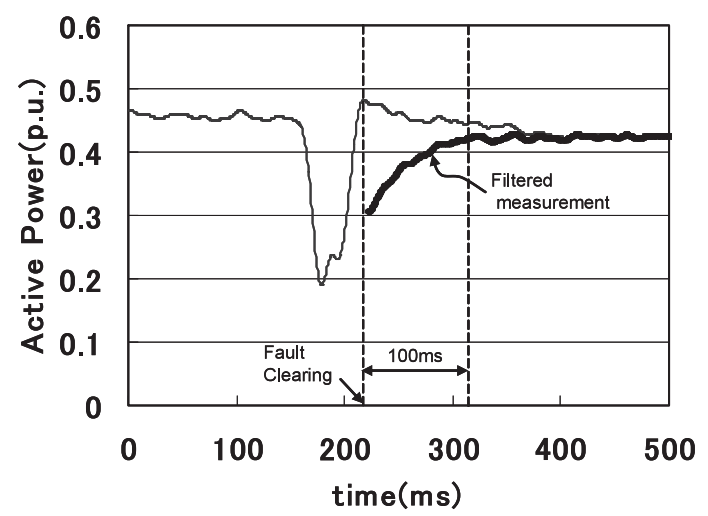

図 12 計測点 Cにおける提案手法適用後の 有効電力波形

Fig. 12. Filtered active power result by the proposed method (measurement node C).

定し, 分類実績ケースから推定した動特性モデル・パラメー 夕を活用することにより故障除去後の有効電力計測波形か ら過渡特性分を低減する提案手法は, 安定化システムが観 測利用可能な故障除去直後の短時間領域における負荷量の 推定に有効性があることを確認した。なお，一般的なディ ジタルリレーの性能から推測すると, 本手法のオンライン 演算処理（提案処理フローの処理手順 (Step 0) に相当する 


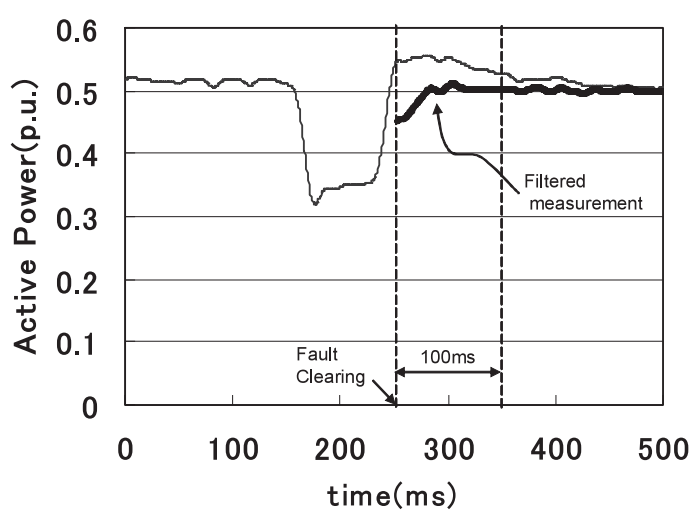

図 13 計測点 D における提案手法適用後の 有効電力波形

Fig. 13. Filtered active power result by the proposed method (measurement node D).

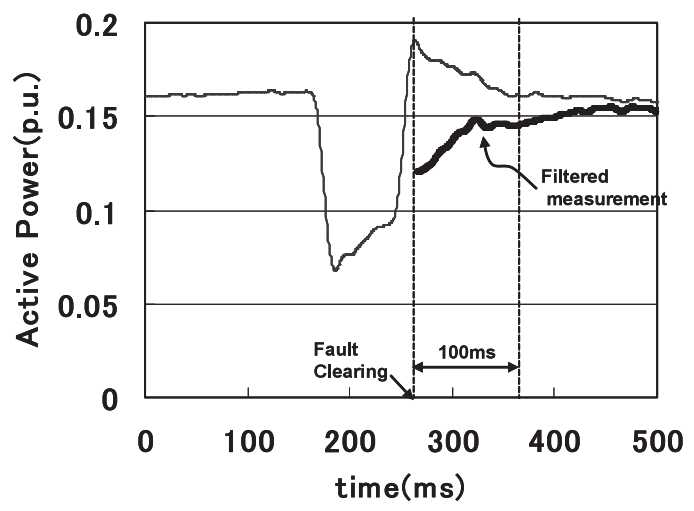

図 14 計測点 $\mathrm{E}$ における提案手法適用後の 有効電力波形

Fig. 14. Filtered active power result by the proposed method (measurement node E).

オフライン処理を除く）そのものに要する時間は $10 \mathrm{~ms}$ 以 内と考えられる。

\section{6. おわりに}

本論文では，周波数安定化システムにおける適用を想定 して，過去に計測された故障実績データの特性分析情報を 用いた新しい負荷脱落量推定方法について述べた。本論文 で得られた知見を以下にまとめる。

（1）提案手法のベースとなる，動特性を考慮した負荷 モデルの動特性パラメータ $\left(K_{d}, T_{d}\right)$ に着目して, 中部電 力主要変電所で計測された故障実績データを使用して特性 を分析した。その結果， $K_{d}$ と $T_{d}$ は強い線形相関を示すと いう特質を確認した。また， $K_{d}$ は故障発生時の電圧低下に 依存することを理論的に考察し，特性モデル式の妥当性を 実績データにより確認した。

（2）ただし，故障実績データの特性を分析するには，季 節や時間帯，計測地点といった条件にしたがいあらかじめ 実績データを分類し取り扱う必要がある。

（3）過去に計測された故障実績データの特性分析によ
る情報を活用することにより故障除去直後の短時間領域に おける電圧と有効電力計測波形に基づいて負荷脱落量をオ ンライン推定する手法を提案した。提案手法は，特性情報 の利用により故障除去直後の負荷の過渡特性分を効率的に 低減することを特徵とする。

（4）提案手法を複数の故障実績データを用いて検証を 行った。その結果, 故障除去直後 $100 \mathrm{~ms}$ 間の計測波形デー 夕に基づいて $1 \%$ 台の誤差（故障前負荷量ベース）で負荷 脱落量をオンライン推定することができ, 提案手法の有効 性を確認するとともに安定化システムでの適用可能性を示 した。

今後，提案手法に対する詳細検証のために他の季節や計 測点の故障実績データによる分析，大幅電圧低下時の脱落 量飽和による影響の検証, 計測点の下位に電源がある場合 など故障除去後の周波数変動の影響分析，および本検討結 果に基づいて安定化システムへの適用方法について検討を 行う予定である。

(平成 17 年 7 月 29 日受付，平成 18 年 2 月 2 日再受付)

\section{文 献}

（1）系統脱調・事故波及防止リレー技術調査専門委員会：「系統脱調・事 故波及防止リレー技術」, 電気学会技術報告, No.801 (2002)

(2) T. Fukuda, T. Muramoto, H. Oshida, T. Gouda, M. Nakamura, and T. Narita: "Development and Practical Application of the New SSC Considering Load Rejection During Fault", The Papers of Technical Meeting on Power \& Energy, IEE Japan, PE-87, No.138-159, pp.131-139 (1987) (in Japanese) 福田朋悟 - 村元俊昭 - 押田秀治 - 合田忠弘 - 中村正則 - 成田利春 : 「事故中の負荷脱落を考慮した新型 SSC の開発と実用化」, 電気学会 電力技術研資, PE-87, No.138-159, pp.131-139 (1987)

(3) N. Taniguchi, K. Ueda, T. Katou, and H. Oono: "Frequency Stabilization Control in an Emergency", The Papers of Technical Meeting on Power \& Energy, IEE Japan, PE-86, No.111-129, pp.51-60 (1986) (in Japanese) 谷口治人 ·植田清隆·加藤龍義・大野博孝:「緊急時周波数安定化制 御」, 電気学会電力技術研資, PE-86, No.111-129, pp.51-60 (1986)

(4) D.J. Hill: "Nonlinear Dynamic Mode Load Models with Recovery for Voltage Stability Studies", IEEE Trans. Power Syst., Vol.8, No.1, pp.166-176 (1993-2)

(5) IEEE Task Force on Load Representation for Dynamic Performance: "Standard Load Models for Power Flow and Dynamic Performance Simulation", IEEE Trans. Power Syst., Vol.10, No.3, pp.1302-1313 (1995-8)

(6) Y. Onoue, N. Saitou, Y. Tabata, K. Yokoi, H. Itou, H. Hashimoto, K. Kibi, and Y. Kowada: "A Basic Study on the New Estimation Method of Dynamic Load Characteristics", 2002 National Convention Record IEE Japan, Vol.6, pp.464-465 (2002) (in Japanese)

尾上幸浩 - 斎藤宣俊 - 田畑康人 · 横井浩一 - 伊藤久徳 - 橋本博幸 吉備和仁・小和田靖之：「負荷脱落量推定手法に関する一検討」, 平 14 電気学会全国大会, Vol.6, pp.464-465 (2002)

( 7 ) P. Kundur: Power System Stability and Control, Mcgraw-Hill (1993)

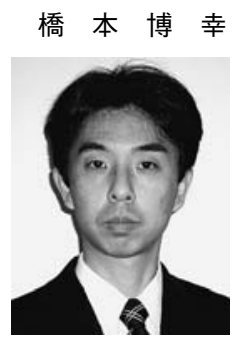

（正員） 1970 年 3 月 21 日生。1995 年 3 月京都 大学大学院工学研究科電気工学専攻修士課程修了。 同年 4 月三菱電機 (株) 入社。現在，同社先端技術 総合研究所に勤務。電力システムの安定度解析 · 評価や系統安定化システムの研究開発の他，需給 計画, 電力自由化関連システムの研究開発に従事。 


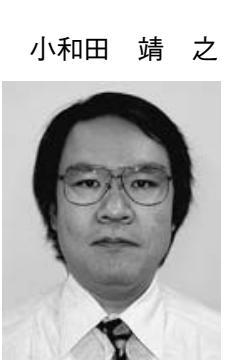

斎 藤 宣 俊 (正員) 1968 年 12 月 23 日生。 1993 年 3 月山梨 大学大学院工学研究科修士課程修了。同年 4 月三 菱電機 (株) 入社。現在, 系統変電システム事業 所保護制御製造部において電力システムの解析 . 制御に関する研究・開発に従事。

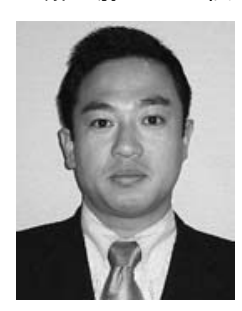
大学大学院工学研究科修士課程修了。同年 4 月中 部電力 (株) 入社。津電力センター変電技術課に て保護・制御装置の運用・保守業務に従事。1998 年電気学会優秀論文発表賞受賞。

尾 上 幸 浩 （正員） 1972 年 8 月 4 日生。1993 年 3 月大分工

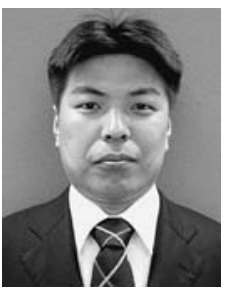

業高等専門学校電気工学科卒業。同年 4 月中部電 力 (株) 入社。現在, 系統運用部給電調査グルー プにて系統解析および系統運用に関する業務に従 事。2002 年電気学会優秀論文発表賞受賞。

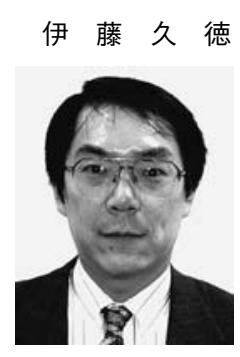

(正員) 1962 年 4 月 27 日生。 1985 年 3 月東京 工業大学工学部電気電子工学科卒業。同年 4 月中 部電力 (株) 入社。現在, 工務部発変電グループ にて保護 ·制御装置の開発 ·計画 · 運営管理業務 に従事。1 996 年電気学会進歩賞受賞。 